\title{
Transcranial Direct Current Stimulation: From Basic Research on Psychological Processes to Rehabilitation
}

\author{
Thiago Leiros Costa ${ }^{1}$ \\ Departamento de Psicologia Experimental da Universidade de São Paulo, São Paulo, \\ São Paulo, Brasil \\ Paulo Sérgio Boggio \\ Laboratório de Neurociência Cognitiva e Social da Universidade Presbiteriana Mackenzie, \\ São Paulo, São Paulo, Brasil \\ Dora Fix Ventura \\ Departamento de Psicologia Experimental da Universidade de São Paulo, São Paulo, \\ São Paulo, Brasil
}

\begin{abstract}
Transcranial direct current stimulation (tDCS) is an "old/new" noninvasive brain modulation technique that has gained increasing popularity and relevance in psychology and neuroscience. The contemporary tDCS procedure is effective and painless. It was shown to modulate motor performance and several sensory and cognitive functions. It can be used to study cortical organization and clarify brain-behavior relationships. Using tDCS for rehabilitation is a promising strategy, and numerous publications suggest that it can be used alone or combined to augment the outcomes of behavioral training and pharmacological interventions. Compared with other brain modulation techniques, it has the advantage of being noninvasive and safe, with easy and effective placebo controls. Its efficacy, low cost, and ease of use make tDCS a very convenient tool for researchers in developing countries. This review introduces tDCS to a new audience and seeks to inspire future investigations in the field. We highlight work that illustrates the main concepts and applications of tDCS as a basic research and rehabilitation tool.
\end{abstract}

Keywords: Transcranial Direct Current Stimulation, basic research, rehabilitation.

\section{Estimulação Transcraniana por Corrente Contínua: Da Pesquisa Básica sobre Processos Psicológicos Básicos à Reabilitação}

\section{Resumo}

Estimulação Transcraniana por Corrente Contínua (ETCC) é uma técnica de estimulação cerebral nãoinvasiva com crescente popularidade na pesquisa em psicologia e neurociências. A aplicação da ETCC é indolor, eficaz e pode afetar o desempenho motor, sensorial e cognitivo. ETCC pode ser usada para estudar a organização cortical e relações entre cérebro e comportamento. Seu uso clínico também é relevante e vários estudos sugerem que pode ser aplicada só ou como complemento a intervenções com-

1 Mailing address: Departamento de Psicologia Experimental, Instituto de Psicologia, Universidade de São Paulo, Av. Prof Mello Moraes,1721, Butantã, São Paulo, Brasil 05508-900. E-mail: e.thiagocosta@gmail.com, psboggio@gmail.com and dventura@usp.br

Acknowledgements: The authors and laboratories received support from Fundação de Amparo à Pesquisa do Estado de São Paulo (FAPESP), Conselho Nacional de Desenvolvimento Científico e Tecnológico (CNPq), and Coordenação de Aperfeiçoamento de Pessoal de Nível Superior (CAPES). Thiago L. Costa has a FAPESP doctoral scholarship (\#2011/10794-9). Dora F. Ventura and Paulo S. Boggio are CNPq research fellows. 
portamentais ou farmacológicas. Quando comparada a outras técnicas de modulação cerebral a ETCC tem a vantagem de ser não-invasiva, segura e com um controle placebo eficaz. O baixo-custo, eficácia e praticidade da técnica torna a ETCC especialmente conveniente para pesquisadores em países em desenvolvimento. A revisão a seguir se propõe a apresentar a ETCC para um novo público e inspirar futuras investigações no campo. Serão apresentados trabalhos que ilustram os principais conceitos e aplicações da ETCC no campo da pesquisa básica e clínica.

Palavras-chave: Estimulação Transcraniana por Corrente Contínua, reabilitação, pesquisa básica.

\section{Estimulación Transcraneal con Corriente Directa: De la Investigación Básica sobre Procesos Psicológicos a la Rehabilitación}

\section{Resumen}

La Estimulación Transcraneal con Corriente Directa (ETCD) es una técnica no invasiva de modulación del cerebro con cresciente popularidad y relevancia para la psicología y las neurociencias. El procedimiento ETCD contemporáneo es efectivo y sin dolor. ETCD puede modular el rendimiento motor y varias funciones sensoriales y cognitivas. Se puede utilizar para estudiar la organización cortical y clarificar las relaciones cerebro-conducta. Uso de ETCD para la rehabilitación es una estrategia prometedora y un número de publicaciones sugieren que puede ser utilizada sola o para impulsar los resultados de intervenciones comportamentales y farmacológicas. En comparación con otras técnicas de modulación del cerebro, tiene la ventaja de ser no invasiva y segura, con un control placebo fácil y eficaz. Su eficacia, bajo costo y facilidad de uso hacen ETCD una herramienta adequada para los investigadores en los países en desarrollo. La siguiente revisión pretende introducir ETCD a un nuevo público y inspirar futuras investigaciones en el campo. Vamos a destacar obras que ilustran los principales conceptos y aplicaciones de ETCD en la investigación básica y clínica.

Palabras clave: Estimulación Transcraneal con Corriente Directa, rehabilitación, investigación básica.

\section{Principles and Mechanisms of Action}

Since Nitsche and Paulus (2000) and Priori, Berardelli, Rona, Accornero, and Manfredi (1998), introduced the contemporary transcranial direct current stimulation (tDCS) procedure, hundreds of researchers have employed it successfully (Kuo \& Nitsche, 2012; Nitsche et al., 2008; Zaghi, Acar, Hultgren, Boggio, \& Fregni, 2010), and the technique is becoming well known among neuroscientists, psychologists, and even the lay public. A search for the keywords "transcranial direct current stimulation" in PubMed currently retrieves more than 800 articles, and the number is continuously growing. Transcranial direct current stimulation is a noninvasive brain stimulation technique that consists of delivering low-intensity constant electrical currents through large nonmetallic saline-soaked electrodes that are positioned over the intact scalp. Research over the last 15 years indicates that this is a promising technique for psychological and neuroscientific research.

Transcranial direct current stimulation devices have anode and cathode electrodes. Stimulation with the anode is generally excitatory, whereas stimulation with the cathode is generally inhibitory. These polarity-dependent effects are related to the modulation of spontaneous neuronal activity. Anodal stimulation induces brief depolarization of the resting membrane potential, whereas cathodal stimulation has the opposite effect. This polarity-dependent nature of the technique is very convenient for a number of investigations of brain-behavior relation- 
ships and different rehabilitative strategies. For example, to study hemispheric specializations, one brain hemisphere may be inhibited while the other one is excited (Fecteau, Knoch, et al., 2007; Fecteau, Pascual-Leone, et al., 2007). The same rationale can be used for the rehabilitation of unilateral lesions.

Noninvasive brain stimulation techniques allow clinical and basic investigations of complex brain-behavior interactions. Compared with other noninvasive brain stimulation techniques, such as transcranial magnetic stimulation (TMS) and repetitive TMS (rTMS), tDCS has a number of convenient characteristics. It is highly portable, affordable, and painless, with rare mild and transient side effects (Brunoni et al., 2012) and a very effective placebo control (Nitsche et al., 2008). Transcranial direct current stimulation does not lead to direct depolarization of the cells in the stimulated area as TMS does. Because low-intensity currents are used, tDCS modulates resting membrane potentials, thus making it either easier or harder for cells to fire, depending on the stimulation polarity. Therefore, performing numerous behavioral tasks while subjects receive $\mathrm{tDCS}$ is possible because ongoing brain activity is not interrupted.

The safety of tDCS is another important advantage. Nonmedical professionals apply tDCS in nonhospital research facilities worldwide. The extant literature does not present examples of significant adverse events induced by tDCS or indicate significant risks associated with such low-current stimulation. The adequacy of this approach has been reinforced only recently. Nevertheless, having medical assistance is advisable when dealing with clinical populations.

Although a consensus appears to have been reached about the safety of tDCS procedures, the complete mechanisms of action have not yet been described. The main findings in this field may be summarized as the following: (a) the effects of tDCS appear to involve different mechanisms during and after stimulation, (b) the effects during tDCS might be explained by the modulation of resting membrane potentials in the stimulated area, (c) the effects after tDCS might be based on "long-term potentiation (LTP)-like" and "long-term depression (LTD)-like" plasticity mechanisms, and (d) the effects of tDCS are site-specific but not site-limited.

During tDCS, the current modulates the stimulated cells to be either closer to the firing threshold or more hyperpolarized, depending on stimulation polarity. The increase or decrease in cellular activity induced by tDCS appears to lead to "LTP-like" and "LTD-like" activity after the stimulation ceases. This notion is reinforced by the fact that post-tDCS effects were abolished by the administration of an $N$-methyl-D-aspartate receptor agonist, which did not alter the effects of tDCS during stimulation (Nitsche et al., 2003). The cellular and molecular mechanisms that underlie the effects of tDCS were recently reviewed by Medeiros et al. (2012) and Stagg and Nitsche (2011).

Transcranial direct current stimulation may be specific to the stimulated site, but its effects are frequently not limited to it. For example, tDCS of the somatosensory cortex has modulatory effects on thalamo-cortical synapses at presynaptic sites (Márquez-Ruiz et al., 2012). Transcranial direct current stimulation also induced changes in regional cerebral blood flow in functionally related cortical areas that did not receive tDCS (Zheng, Alsop, \& Schlaug, 2011). These are two examples of cases in which tDCS induced changes in brain activity outside the stimulated sites. Given the intricate nature of neural networks, this should be considered when discussing the results.

\section{From Basic Research on Psychological Processes to Rehabilitation}

Transcranial direct current stimulation has been used as a research tool in studies of sensory and perceptual processes, memory, decision making, and language. Knowledge that has been gained from these experiments has been translated to clinical research on such topics as craving, memory, motor disorders, and depression. We highlight some of these works below. 
Table 1

Examples of tDCS Parameters Used and Results Reported

\begin{tabular}{|c|c|c|c|}
\hline Author & Montage & tDCS parameters & Results \\
\hline $\begin{array}{l}\text { Nitsche \& Paulus, } \\
2000\end{array}$ & $\begin{array}{c}\text { M1 (identified by } \\
\text { TMS); } \\
\text { right supra } \\
\text { orbital }\end{array}$ & $\begin{array}{l}5 \times 7 \mathrm{~cm} \\
1 \mathrm{~mA} \\
1-5 \mathrm{~min}\end{array}$ & $\begin{array}{l}\text { Polarity-specific tDCS effects on motor cortex } \\
\text { excitability }\end{array}$ \\
\hline Boggio, 2006 & $\begin{array}{l}\text { F3; right supra } \\
\text { orbital }\end{array}$ & $\begin{array}{l}5 \times 7 \mathrm{~cm} \\
1 \mathrm{~mA} \\
20 \mathrm{~min}\end{array}$ & $\begin{array}{l}\text { Anodal tDCS increased working memory } \\
\text { performance in Parkinson's disease }\end{array}$ \\
\hline $\begin{array}{l}\text { Fecteau, Knoch, et } \\
\text { al., } 2007\end{array}$ & F3-F4 & $\begin{array}{l}5 \times 7 \mathrm{~cm} \\
2 \mathrm{~mA} \\
15 \mathrm{~min}\end{array}$ & $\begin{array}{l}\text { tDCS reduced risk taking, with stronger effect } \\
\text { with anode on the right }\end{array}$ \\
\hline Boggio et al., 2009 & $\begin{array}{c}\text { F3; right } \\
\text { supra orbital }\end{array}$ & $\begin{array}{l}5 \times 7 \mathrm{~cm} \\
2 \mathrm{~mA} \\
5 \mathrm{~min}\end{array}$ & $\begin{array}{c}\text { Anodal tDCS reduced responses to physical pain } \\
\text { figures }\end{array}$ \\
\hline $\begin{array}{l}\text { Costa, Nagy, } \\
\text { Barboni, Boggio, } \\
\text { \& Ventura, } 2012\end{array}$ & $\mathrm{Oz}-\mathrm{Cz}$ & $\begin{array}{l}5 \times 5 \mathrm{~cm} \\
1.5 \mathrm{~mA} \\
20 \mathrm{~min}\end{array}$ & $\begin{array}{l}\text { Cathodal tDCS differentially affected visual } \\
\text { pathways involved in color vision }\end{array}$ \\
\hline $\begin{array}{l}\text { Bardi, Kanai, } \\
\quad \text { Mapelli, } \\
\text { \& Walsh, } 2012\end{array}$ & P3-P4 & $\begin{array}{l}3 \times 3 \mathrm{~cm} \\
1.5 \mathrm{~mA} \\
15 \mathrm{~min}\end{array}$ & $\begin{array}{l}\text { tDCS unveiled posterior parietal cortex } \\
\text { hemispheric differences in attending to low } v s \text {. } \\
\text { high salience visual stimuli }\end{array}$ \\
\hline $\begin{array}{l}\text { Brunoni, Valiengo, } \\
\text { et al. } 2013\end{array}$ & F3-F4 & $\begin{array}{l}5 \times 5 \mathrm{~cm} \\
2 \mathrm{~mA} \\
30 \mathrm{~min} \text { for } 10 \\
\text { days }\end{array}$ & $\begin{array}{c}\text { Anodal tDCS was equivalent to sertraline ( } 50 \\
\text { mg/day) in major depression, and combining } \\
\text { sertraline with tDCS had a stronger effect than } \\
\text { either alone }\end{array}$ \\
\hline
\end{tabular}

Note. Montage refers to the site where electrodes were placed (in the 10-20 International System). The tDCS parameters describe electrode size, current strength, and stimulation duration, respectively.

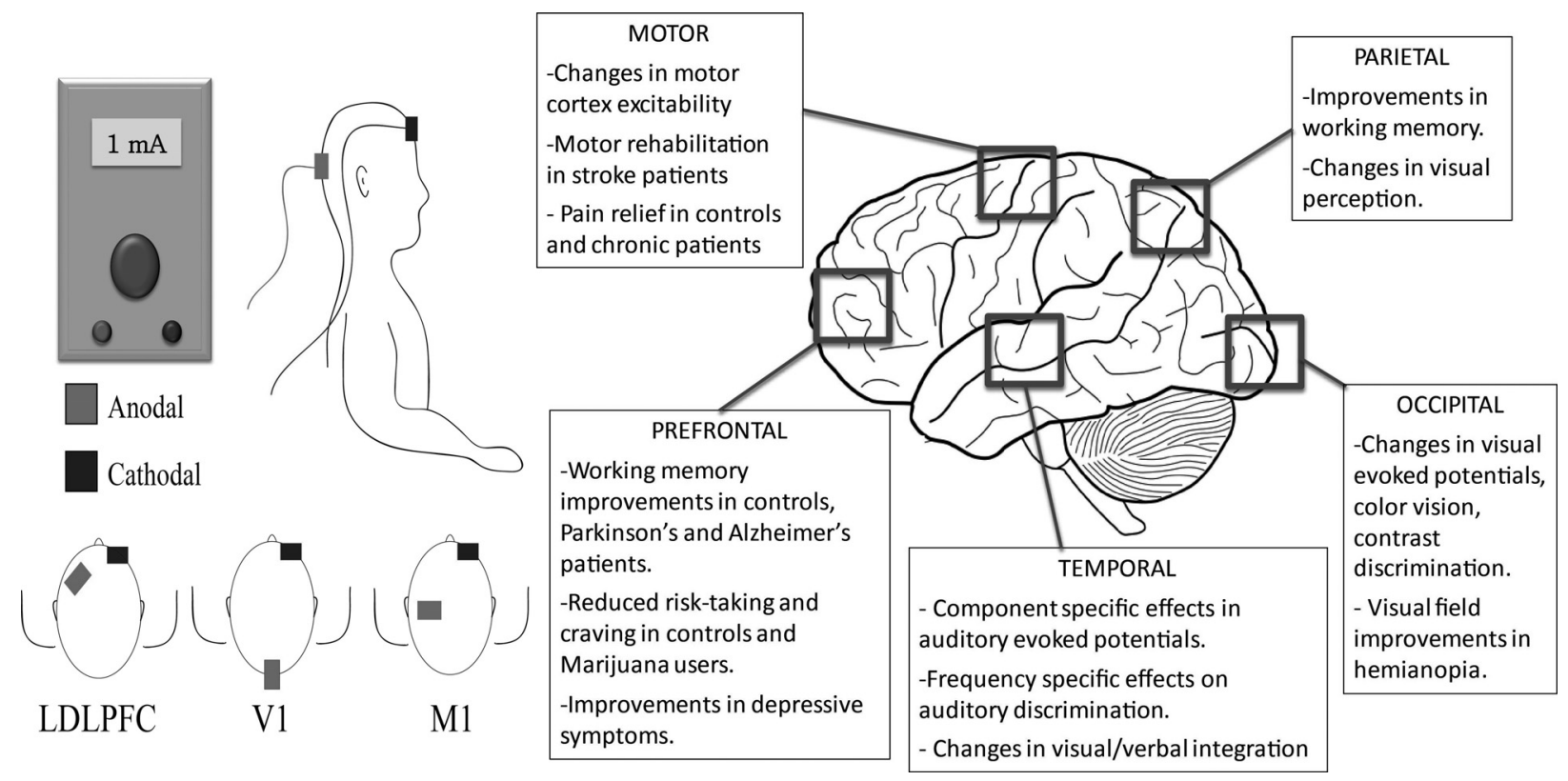

Figure 1. (Left) Schematic example of tDCS device and popular electrode montages. (Right) Summary of the main results presented in the present review. 


\section{Motor}

The first contemporary investigations of tDCS targeted the motor cortex in healthy individuals. Transcranial direct current stimulation was shown to significantly affect the excitability of the motor cortex in a polarity-specific manner (Nitsche \& Paulus, 2000; Priori et al., 1998). Transcranial direct current stimulation is also being used in motor rehabilitation research. Anodal M1 tDCS of the affected hemisphere or cathodal M1 tDCS of the unaffected hemisphere led to motor improvements in stroke patients (Fregni, Boggio, et al., 2006). Boggio et al. (2007) subsequently showed that M1 tDCS led to motor improvement with daily but not weekly sessions of stimulation. These results illustrate two important concepts in tDCS research. First, the inhibitory stimulation of competing areas may lead to improvements in performance in the area of interest. Second, repeated daily sessions appear to be more effective and lead to longerlasting effects than single or spaced sessions.

\section{Auditory and Visual}

The effect of tDCS on basic sensory processes has also been demonstrated. Transcranial direct current stimulation of the temporal cortex can have a frequency-specific effect on auditory processing (Ladeira et al., 2011) and modulate different components of auditory-evoked potentials, depending on the stimulation site (Zaehle, Beretta, Jäncke, Herrmann, \& Sandmann, 2011). Therefore, different brain areas may be differentially related to different components of auditory-evoked potential. This finding illustrates how tDCS may be used as a tool to investigate cortical organization. Another example is the work of Bardi et al. (2012) on the asymmetry of processing low - and high-salience visual stimuli in the posterior parietal cortex (PPC). These authors found a differential effect of tDCS on right $v s$. left PPC, suggesting greater involvement of the left PPC in attending to low-salience stimuli and right PPC in attending to high-salience stimuli. Transcranial direct current stimulation has also been shown to distinctly affect different sensory pathways in the same cortical area. Costa et al. (2012) found that tDCS over V1 has differential effects on dif- ferent color vision processing pathways. Thus, tDCS may also be used to study the organization of pathways within a single cortical area. Interestingly, tDCS can unveil gender differences in cortical function. Bilateral cathodal tDCS of the temporal cortex in a visual/verbal integration task disrupted performance only in males (Lapenta, Fregni, Oberman, \& Boggio, 2012).

The fields of rehabilitation and clinical research might be where the use of tDCS is most promising. Because of its low cost, safety, and portability, it may be adapted for home use and even be used as a substitute for medications in subjects who are unable or unwilling to take them (Brunoni, Boggio, et al., 2013). Numerous publications show that tDCS can be used to boost rehabilitative training. For example, tDCS was shown to expand the visual field in hemianopic patients, augmenting the outcome of standard behavioral training on a number of occasions (Plow, Obretenova, Fregni, Pascual-Leone, \& Merabet, 2012; Plow et al., 2011; Plow, Obretenova, Jackson, \& Merabet, 2012).

\section{Learning and Memory}

Numerous studies that used tDCS can be found in the field of basic research on cognitive neuroscience. Numerous successful tDCS investigations on memory function and rehabilitation have been conducted. The first study in this field was performed by Fregni et al. (2005), showing that anodal tDCS over the left dorsolateral prefrontal cortex (dlPFC) improved working memory. Subsequently, researchers used tDCS to investigate the role of the parietal cortex in working memory. Sandrini, Fertonani, Cohen, and Miniussi (2012), reported a double dissociation of working memory in different PPC hemispheres that depended on task complexity. In a similar study, Jones and Berryhill (2012) found that only participants with high working memory capacity benefitted from PPC tDCS during a change detection task. These authors concluded that the parietal contribution to working memory might differ in individuals with low $v s$. high working memory capacity. This is an example of how tDCS research might elucidate individual differences in cortical function. In clinical pop- 
ulations, tDCS was found to improve memory performance in Parkinson's disease (Boggio, 2006) and Alzheimer's disease (Boggio et al., 2009; Ferrucci et al., 2008).

Transcranial direct current stimulation can also be used to investigate and augment learning processes. Stimulation of the premotor cortex during a motor sequence learning task was ineffective, but premotor cortex tDCS during rapid-eye-movement sleep modulated the consolidation of motor sequence learning (Kuo \& Nitsche, 2012; Nitsche et al., 2010). Cathodal stimulation of M1 led to a decrease in the acquisition of action-related words, making a case for the involvement of M1 in the acquisition of this kind of language processing. Other examples of the effects of tDCS on cognition may be found in the review by Kuo and Nitsche (2012).

\section{Decision Making}

Numerous studies have shown that tDCS over the PFC can significantly affect decision making in different tasks and populations. Bilateral dlPFC tDCS diminished risk taking in healthy participants, with more pronounced effects with anode stimulation of the right dlPFC (Fecteau, Knoch, et al., 2007; Fecteau, Pascual-Leone, et al., 2007). Bilateral tDCS of the dIPFC was later shown to modulate food craving in healthy adults (Fregni et al., 2008) and performance in a gambling task in older adults (Boggio, Campanhã, et al., 2010). Dorsolateral prefrontal cortex tDCS was also shown to diminish risk taking and marijuana craving in a sample of 25 chronic marijuana users (Boggio, Zaghi, et al., 2010). These results suggest that $\mathrm{tDCS}$ can be valuable in the treatment of substance abuse, eating disorders, gambling disorders, and nonadaptive risk-taking behavior.

\section{Pain}

Transcranial direct current stimulation can modulate pain perception in healthy volunteers (Antal et al., 2008) and clinical populations with fibromyalgia (Fregni, Gimenes, et al., 2006) and spinal cord injury (Soler et al., 2010). In a recent review, Zaghi, Heine, and Fregni (2009) concluded that tDCS is the most cost-effective treatment for central pain (for treatments that last less than 5 years) compared with other neuromodulatory techniques (e.g., rTMS or EDCS). Dozens of publications have reported different tDCS protocols to treat different pain populations, but M1 is the most frequently targeted cortical area for this purpose (Mylius, Borckardt, \& Lefaucheur, 2012).

Combining tDCS with standard behavioral and pharmacological pain treatments is very promising. Visual illusion-based interventions to treat pain in spinal cord-injured patients was shown to be effective. Patients who received M1 anodal stimulation combined with visual illusion therapy exhibited a significant decrease in pain scores compared with patients who received illusion therapy alone, and these effects lasted for at least 12 weeks (Soler et al., 2010). Using a similar approach, Kumru et al. (2013) reported the normalization of heat and pain thresholds in the dermatomes rostral to the spinal cord lesion level.

A few reports in the literature suggest that combining tDCS with pharmacological treatments may result in a decrease in the necessary medication dosages. Borckardt et al. (2011) showed that participants who underwent an endoscopic procedure required $22 \%$ less analgesics when they received tDCS. Borckardt et al. (2013) then showed that patients who received 80 min of tDCS after total knee arthroplasty needed approximately half of the analgesics compared with the placebo tDCS group.

\section{Depression}

Neuropsychiatric treatment is another field where tDCS is a promising tool. The treatment of depression is one of the applications in which the greatest advances have been seen. Boggio et al. (2007) showed that patients with major depression performed better in an affective Go-No-Go task when they received anodal tDCS over the left dlPFC. Rigonatti et al. (2008) found that anodal tDCS over the left dIPFC exerted effects similar to $20 \mathrm{mg}$ /day fluoxetine treatment. In a sample of 120 patients with major depressive disorder, Brunoni, Valiengo, et al. (2013) showed that anodal tDCS of the left dIPFC had effects similar to sertraline treatment $(50 \mathrm{mg} /$ day $)$. The authors 
also found that combining sertraline with tDCS led to an improvement that was greater than either treatment modality alone. This study showed that tDCS can be very effectively combined with pharmacological treatments.

\section{Conclusion}

In summary, tDCS can be used to investigate cortical organization, brain-behavior relationships, gender differences, and various sensory and cognitive processes. From the clinical and rehabilitative perspective, tDCS can be used as a rehabilitation tool alone or combined with behavioral training. Transcranial direct current stimulation can also replace or complement pharmacotherapies. Although numerous studies have shown the efficacy of this technique for clinical and research use, it is still far from commercial use, and several goals have to be met first, thus providing many research opportunities. The mechanisms of action of tDCS need further clarification. The development of models that utilize awake animals in parallel with human research is critical. Parametric investigations are also needed. Moreover, the popularization of recently introduced high-definition tDCS devices (Borckardt et al., 2012) will allow more focal stimulation protocols, which may lead to important results. The present review makes a case for the use of tDCS in basic and clinical research. It is an effective and affordable technique that can be used in nonhospital settings, making it especially well suited for psychological research.

\section{References}

Antal, A., Brepohl, N., Poreisz, C., Boros, K., Csifcsak, G., \& Paulus, W. (2008). Transcranial direct current stimulation over somatosensory cortex decreases experimentally induced acute pain perception. The Clinical Journal of Pain, 24(1), 56-63. doi:10.1097/AJP.0b013e318157233b

Bardi, L., Kanai, R., Mapelli, D., \& Walsh, V. (2012). Direct current stimulation (tDCS) reveals parietal asymmetry in local/global and salience-based selection. Cortex, 49(3), 850-860. doi:10.1016/j.cortex.2012.04.016

Borckardt, J. J., Bikson, M., Frohman, H., Reeves, S. T., Datta, A., Bansal, V., ...George, M. S.
(2012). A pilot study of the tolerability and effects of high-definition transcranial direct current stimulation (HD-tDCS) on pain perception. Journal of Pain, 13(2), 112-120. doi:10.1016/j. jpain.2011.07.001

Borckardt, J. J., Reeves, S. T., Robinson, S. M., May, J. T., Epperson, T. I., Gunselman, R. J., ...George, M. S. (2013). Transcranial direct current stimulation (tDCS) reduces postsurgical opioid consumption in total knee arthroplasty (TKA). The Clinical Journal of Pain, 29, 925928. doi:10.1097/AJP.0b013e31827e32be

Borckardt, J. J., Romagnuolo, J., Reeves, S. T., Madan, A., Frohman, H., Beam, W., \& George, M. S. (2011). Feasibility, safety, and effectiveness of transcranial direct current stimulation for decreasing post-ERCP pain: A randomized, sham-controlled, pilot study. Gastrointestinal Endoscopy, 73, 1158-1164. doi:10.1016/j. gie.2011.01.050

Boggio, P. S. (2006). Efeitos da estimulação transcraniana por corrente contínua sobre memória operacional e controle motor (Tese de doutorado, Universidade de São Paulo, SP, Brasil).

Boggio, P. S., Campanhã, C., Valasek, C. A., Fecteau, S., Pascual-Leone, A., \& Fregni, F. (2010). Modulation of decision-making in a gambling task in older adults with transcranial direct current stimulation. European Journal of Neuroscience, 31(3), 593-597. doi:10.1111/j.14609568.2010.07080.x

Boggio, P. S., Khoury, L. P., Martins, D. C. S., Martins, O. E. M. S., Macedo, E. C., \& Fregni, F. (2009). Temporal cortex direct current stimulation enhances performance on a visual recognition memory task in Alzheimer disease. Journal of Neurology Neurosurgery and Psychiatry, 80(4), 444-447. doi:10.1136/jnnp.2007.141853

Boggio, P. S., Nunes, A., Rigonatti, S. P., Nitsche, M. A., Pascual-Leone, A., \& Fregni, F. (2007). Repeated sessions of non-invasive brain DC stimulation is associated with motor function improvement in stroke patients. Restorative Neurology and Neuroscience, 25, 123-129.

Boggio, P. S., Zaghi, S., Villani, A. B., Fecteau, S., Pascual-Leone, A., \& Fregni, F. (2010). Modulation of risk-taking in marijuana users by transcranial direct current stimulation (tDCS) of the dorsolateral prefrontal cortex (DLPFC). Drug and Alcohol Dependence, 112, 220-225. doi:10.1016/j.drugalcdep.2010.06.019 
Brunoni, A. R., Amadera, J., Berbel, B., Volz, M. S., Rizzerio, B. G., \& Fregni, F. (2012). A systematic review on reporting and assessment of adverse effects associated with transcranial direct current stimulation. International Journal of Neuropsychopharmacology, 14(8), 1133-1145. doi:10.1017/S1461145710001690

Brunoni, A. R., Boggio, P. S., Ferrucci, R., Priori, A., \& Fregni, F. (2013). Transcranial direct current stimulation: Challenges, opportunities and impact on psychiatry and neurorehabilitation. Frontiers in Psychiatry, 4, 19. doi:10.3389/ fpsyt.2013.00019

Brunoni, A. R., Valiengo, L., Baccaro, A., Zanão, T. A., de Oliveira, J. F., Goulart, A., ...Fregni, F. (2013). The sertraline vs. electrical current therapy for treating depression clinical study: Results from a factorial, randomized, controlled trial. JAMA Psychiatry, 70(4), 383-391. doi:10.1001/2013.jamapsychiatry.32

Costa, T. L., Nagy, B. V., Barboni, M. T., Boggio, P. S., \& Ventura, D. F. (2012). Transcranial direct current stimulation modulates human color discrimination in a pathway-specific manner. Frontiers in Psychiatry, 3, 78. doi:10.3389/ fpsyt.2012.00078

Fecteau, S., Knoch, D., Fregni, F., Sultani, N., Boggio, P., \& Pascual-Leone, A. (2007). Diminishing risk-taking behavior by modulating activity in the prefrontal cortex: A direct current stimulation study. Journal of Neuroscience, 27(46), 12500-12505.

Fecteau, S., Pascual-Leone, A., Zald, D. H., Liguori, P., Théoret, H., Boggio, P. S., \& Fregni, F. (2007). Activation of prefrontal cortex by transcranial direct current stimulation reduces appetite for risk during ambiguous decision making. Journal of Neuroscience, 27(23), 6212-6218.

Fregni, F., Boggio, P. S., Mansur, C. G., Wagner, T., Ferreira, M. J., Lima, M. C., ...Pascual-Leone, A. (2006). Transcranial direct current stimulation of the unaffected hemisphere in stroke patients. NeuroReport, 16(14), 1551-1555.

Fregni, F., Boggio, P. S., Nitsche, M., Bermpohl, F., Antal, A., Feredoes, E., ...Pascual-Leone, A. (2005). Anodal transcranial direct current stimulation of prefrontal cortex enhances working memory. Experimental Brain Research, 166(1), 23-30.

Fregni, F., Gimenes, R., Valle, A. C., Ferreira, M. J., Rocha, R. R., Natalle, L., ...Boggio, P. S. (2006). A randomized, sham-controlled, proof of prin- ciple study of transcranial direct current stimulation for the treatment of pain in fibromyalgia. Arthritis \& Rheumatology, 54, 3988-3998.

Fregni, F., Orsati, F., Pedrosa, W., Fecteau, S., Tome, F. A., Nitsche, M. A., ...Boggio, P. S. (2008). Transcranial direct current stimulation of the prefrontal cortex modulates the desire for specific foods. Appetite, 51, 34-41. doi:10.1016/j. appet.2007.09.016

Ferrucci, R., Mameli, F., Guidi, I., Mrakic-Sposta, S., Vergari, M., Marceglia, S., ...Priori, A. (2008). Transcranial direct current stimulation improves recognition memory in Alzheimer disease. Neurology, 71(7), 493-498. doi:10.1212/01. wnl.0000317060.43722.a3

Jones, K. T., \& Berryhill, M. E. (2012). Parietal contributions to visual working memory depend on task difficulty. Frontiers in Psychiatry, 3, 81. doi:10.3389/fpsyt.2012.00081

Kumru, H., Soler, D., Vidal, J., Navarro, X., Tormos, J. M., Pascual-Leone, A., \& Valls-Sole, J. (2013). The effects of transcranial direct current stimulation with visual illusion in neuropathic pain due to spinal cord injury: An evoked potentials and quantitative thermal testing study. European Journal of Pain, 17(1), 55-66. doi:10.1002/j.1532-2149.2012.00167.x

Kuo, M., \& Nitsche, M. A. (2012). Effects of transcranial electrical stimulation on cognition. Clinical EEG and Neuroscience, 43(3), 192199. doi:10.1177/1550059412444975

Ladeira, A., Fregni, F., Campanhã, C., Valasek, C. A., De Ridder, D., Brunoni, A. R., \& Boggio, P. S. (2011). Polarity-dependent transcranial direct current stimulation effects on central auditory processing. PLoS One, 6, e25399. doi:10.1371/ journal.pone.0025399

Lapenta, O. M., Fregni, F., Oberman, L. M., \& Boggio, P. S. (2012). Bilateral temporal cortex transcranial direct current stimulation worsens male performance in a multisensory integration task. Neuroscience Letters, 527, 105-109. doi:10.1016/j.neulet.2012.08.076

Márquez-Ruiz, J., Leal-Campanario, R., Sánchez-Campusano, R., Molaee-Ardekani, B., Wendling, F., Miranda, P. C., ...Delgado-García, J. M. (2012). Transcranial direct-current stimulation modulates synaptic mechanisms involved in associative learning in behaving rabbits. Proceedings of the National Academy of Sciences USA, 109, 6710-6715. doi:10.1073/ pnas. 1121147109 
Medeiros, L. F., de Souza, I. C., Vidor, L. P., de Souza, A., Deitos, A., Volz, M. S., ...Torres, I. L. (2012). Neurobiological effects of transcranial direct current stimulation: A review. Frontiers in Psychiatry, 3, 110. doi:10.3389/ fpsyt.2012.00110

Mylius, V., Borckardt, J. J., \& Lefaucheur, J. P. (2012). Noninvasive cortical modulation of experimental pain. Pain, 153(7), 1350-1363. doi:10.1016/j.pain.2012.04.009

Nitsche, M. A., Cohen, L. G., Wassermann, E. M., Priori, A., Lang, N., Antal, A., ...Pascual-Leone, A. (2008). Transcranial direct current stimulation: State of the art 2008. Brain Stimulation, 1(3), 206-223. doi:10.1016/j.brs.2008.06.004

Nitsche, M. A., Fricke, K., Henschke, U., Schlitterlau, A., Liebetanz, D., Lang, N., ...Paulus, W. (2003). Pharmacological modulation of cortical excitability shifts induced by transcranial direct current stimulation in humans. Journal of Physiology, 553, 293-301. doi:10.1113/jphysiol.2003.049916

Nitsche, M. A., Jakoubkova, M., Thirugnanasambandam, N., Schmalfuss, L., Hullemann, S., Sonka, K., ...Happe, S. (2010). Contribution of the premotor cortex to consolidation of motor sequence learning in humans during sleep. Journal of Neurophysiology, 104(5), 2603-2614. doi:10.1152/ jn.00611.2010

Nitsche, M. A., \& Paulus, W. (2000). Excitability changes induced in the human motor cortex by weak transcranial direct current stimulation. Journal of Physiology, 527, 633-639.

Plow, E. B., Obretenova, S. N., Fregni, F., PascualLeone, A., \& Merabet, L. B. (2012). Comparison of visual field training for hemianopia with active versus sham transcranial direct cortical stimulation. Neurorehabilitation and Neural Repair, 26, 616-626. doi:10.1177/1545968311431963

Plow, E. B., Obretenova, S. N., Halko, M. A., Kenkel, S., Jackson, M. L., Pascual-Leone, A., \& Merabet, L. B. (2011). Combining visual rehabilitative training and noninvasive brain stimulation to enhance visual function in patients with hemianopia: A comparative case study. $P M \& R$, 3(9), 825-835. doi:10.1016/j.pmrj.2011.05.026

Plow, E. B., Obretenova, S. N., Jackson, M. L., \& Merabet, L. B. (2012). Temporal profile of functional visual rehabilitative outcomes modulated by transcranial direct current stimulation. $\mathrm{Neu}$ romodulation, 15, 367-373. doi:10.1111/j.15251403.2012.00440.x.
Priori, A., Berardelli, A., Rona, S., Accornero, N., \& Manfredi, M. (1998). Polarization of the human motor cortex through the scalp. NeuroReport, 9, 2257-2260.

Rigonatti, S. P., Boggio, P. S., Myczkowski, M. L., Otta, E., Fiquer, J. T., Ribeiro, R. B., ...Fregni, F. (2008). Transcranial direct stimulation and fluoxetine for the treatment of depression. European Psychiatry, 23(1), 74-76.

Sandrini, M., Fertonani, A., Cohen, L. G., \& Miniussi, C. (2012). Double dissociation of working memory load effects induced by bilateral parietal modulation. Neuropsychologia, 50, 396-402. doi:10.1016/j.neuropsychologia.2011.12.011

Soler, M. D., Kumru, H., Pelayo, R., Vidal, J., Tormos, J. M., Fregni, F., ...Pascual-Leone, A. (2010). Effectiveness of transcranial direct current stimulation and visual illusion on neuropathic pain in spinal cord injury. Brain, 133(9), 2565-2577. doi:10.1093/brain/awq184

Stagg, C., \& Nitsche, M. (2011). Physiological basis of transcranial direct current stimulation. Neuroscientist, 17(1), 37-53. doi:10.1177/1073858410386614

Zaghi, S., Acar, M., Hultgren, B., Boggio, P. S., \& Fregni, F. (2010). Noninvasive brain stimulation with low-intensity electrical currents: Putative mechanisms of action for direct and alternating current stimulation. Neuroscientist, 16(3), 285307. doi:10.1177/1073858409336227

Zaghi, S., Heine, N., \& Fregni, F. (2009). Brain stimulation for the treatment of pain: A review of costs, clinical effects, and mechanisms of treatment for three different central neuromodulatory approaches. Journal of Pain Management, 2(3), 339-352.

Zaehle, T., Beretta, M., Jäncke, L., Herrmann, C. S., \& Sandmann, P. (2011). Excitability changes induced in the human auditory cortex by transcranial direct current stimulation: Direct electrophysiological evidence. Experimental Brain Research, 215(2), 135-140. doi:10.1007/ s00221-011-2879-5.

Zheng, X., Alsop, D. C., \& Schlaug, G. (2011). Effects of transcranial direct current stimulation (tDCS) on human regional cerebral blood flow. Neuroimage, 58(1), 26-33. doi:10.1016/j.neuroimage.2011.06.018

Received: June, 12, 2013

$1^{\text {st }}$ revision: October, 07, 2013 Accepted: October, 14, 2013 